\title{
City Master Plan: \\ Forecasting Methodology Problems (on the example of the Master Plans of Kyiv)
}

\author{
Alla Pleshkanovska \\ Kyiv National University of Construction and Architecture \\ Povitroflotskyj Avenue 31, Kyiv, Ukraine, 03680 \\ ample urban@ukr.net, orcid.org/0000-0001-9370-3570
}

Received 06.05.2019, accepted after revision 06.06.2019

https://doi.org/10.31493/tit1921.0201

\begin{abstract}
The basic document for regulation of the settlement urban development is the Master Plan [1]. The legislative and regulatory framework for regulating the composition, content, approval and approval of this document is very extensive and is based on a broad basis of scientific research and practical experience of domestic and foreign specialists in this field.

The larger the city, the more difficult it is to predict its continued existence. In this article the results of the analysis of historical-geographical, socio-demographic and legislative-normative aspects influencing the regulation of the city development issues (on the example of the historical and current master plans of the city of Kyiv) are covered.

Also are outlined the peculiarities of the formation of the spatial organization of the city territory as a part of the master plans of Kyiv at different historical stages - prior the planning, the period of joining the Russian Empire, the Soviet and the present period. The evolution of models of spatial organization of the city territory is characterized.

The master plans development periodicity is analyzed as well as a conclusion is made about the fallibility of the statutory requirement regarding the indefinite validity of the master plan of the settlement as a basic urban planning document.

Population size (both actual and predicted) acts as a key indicator of settlement development. The article analyzes the dynamics of the population of Kyiv, identifies patterns of influence of positive and negative factors on this indicator, establishes
\end{abstract}

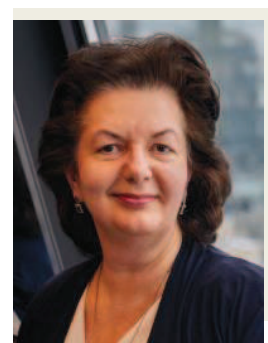

\section{Alla Pleshkanovska}

Professor of Land Management and Cadastre Department

Dr.Tech.Sc., Prof.

faults between the actual and predicted population of Kyiv.

The conclusion is made about the extreme complexity of forecasting the prospects for the development of urban systems. The reasons (accuracy of demographic forecasts, counter intuitiveness of development of complex urban planning system, imperfection of legislative and regulatory base) of impossibility of full realization of master plans of settlements, in particular, of the city of Kyiv are considered.

The recommendations on improvement of the legislative and normative base for development of settlements master plans are given. In particular, the return of the fixed term of the Master Plan, that does not exceed 20 years.

The author's vision of promising directions of development and transformation of the spatial organization of the territory at the present evolutionary stage of its existence of the city of Kyiv is formulated. Namely - a cardinal complex reconstruction of the city.

Keywords: Master Plan, spatial development, population density, demographic forecast, legislative and regulatory framework. 


\section{INTRODUCTION}

The development of a city from foundation, forming and, sometimes stagnation and death, is extremely hard and difficult to predict. However, people are persistently trying to manage this process and to shape the spatial organization of the city in accordance with ideas about a comfortable urban environment at one time or another in the evolutionary development of society.

The main document that defines the directions and parameters of the spatial development of the settlement is the Master Plan.

According to the Law of Ukraine "On Regulation of Urban Planning Activity" (Article 17, Par. 1) "The Master Plan of a settlement is the main type of town planning documentation at the local level intended to reasoning a longterm strategy of planning and development of the territory of a settlement". [1] In this case, the validity of the master plan is not limited, that is, in fact, recognized open-ended. [1, Art. 17, Par. 8].

This applies not only to the new master plans of the settlements, but also to the zoning plans and detailed plans of the territories, which must correspond to the planning decisions of the master plan. It is this position of the Law of Ukraine "On Regulation of Urban Planning Activity" that caused a lot of disputes and problems in the process of developing and agreeing urban planning documentation at the local level, in particular, in the city of Kyiv.

Altogether philosophers and architects, urban planners and simply residents of a certain village are trying to understand the laws of existence and forecasting of the urban systems development. The material presented is based on the analysis of previous studies from several aspects, namely:

- to the issues of spatial organization of the city plan are devoted the works of Bilokon Yu.M., Demin M.M, Ositnyanko A.P., Panchenko T.F., Timokhin V.A., Filvarov H.Y., Fomin I.O.;

- geographical and socio-economic aspects are covered in the works of Bystryakov I.K., Zablotsky G.A., Klyusheichenko E.E., Palekha Yu.M., Stebletska Yu.;
- environmental and socio-demographic issues considered in the works of Libanova E.M., Pribitkova I.M., Solukha B.V., Ustinova I.I.

- legislative and legal aspects of development of master plans are considered by Gleba V.Yu., Dyuzhev S.A., Petrakovska O.S., Smilka V.A.

To what extent does the real spatial organization of the city of Kyiv corresponds to the decisions of the master plan for its development and can the master plan of the settlement be open-ended? Let us try to answer this question by considering the impact of legislative, regulatory, historical, geographical and socioeconomic aspects of city development on the example of the city of Kyiv.

\section{AIM AND RESEARCH METHODS}

The purpose of this study was to understand the regularities of transformation of the functional and planning organization of the city of Kyiv for the purposes of further forecasting its development.

Using the historical method, political, cultural and socio-demographic factors have been identified that influence the need for urban areas and the transformation of urban space. On the basis of a retrospective analysis of the main drafts of the General plans of the city of Kyiv, using the graphoanalytic method, the evolutionary stages of the formation of the functional planning organization of the territory of the city of Kyiv are established.

Using the comparative method, legitimacy of periodicity of development of master plans of Kyiv and influence of legislative and regulatory base on the development of this type of city-building documentation were determined.

On the basis of the forecasting method, the principal directions of further transformation of the functionally planning organization of the territory of the city of Kyiv are formulated.

\section{RESULTS AND EXPLANATIONS}

A) Historical and geographical aspects.

Numerous cartographic materials reflecting the status and prospects of the spatial organi- 
zation of the territory of Kyiv can be divided into four periods [Yu Stebletska, 2].

1) Prior to planning - from the end of the 5 th century to the end of the 17 th century. There is no cartographic evidence of intentions for future development of Kyiv. This information is found only in chronicle sources.

2) Kyiv as a part of the Russian Empire (late 17-19 centuries). During this period were developed:

- the Master Plan of Kyiv in 1695, executed under the leadership of Colonel I. Ushakov - the first document of this type, preserved in more or less full volume;

- the Master Plan of 1787, drafted by General Miller and Real State Advisor Earl Shuvalov;

- the Master plan of Kyiv in 1808 by Architect A. Melensky;

- the Master Plan of 1833 (partially modified in 1837) - the authors: engineer L. Shmegelsky, architects V. Beretti and L. Stanzani;

3) The Soviet period (almost all of the twentieth century);

4) The current planning stage of Kyiv (21st century).

It is on the last two periods that we dwell in detail. The main drawing of the master plans of Kyiv in the Soviet and modern periods, similar scale shown in Fig. 1 and Fig. 2.

On the eve of the First World War, Kyiv was a very well-developed provincial city. Between the years of 1897 and 1914 the population of the city increased from 248 to 626 thousand people. [3] Accordingly the city was expanded. In 1910, the suburbs of Solomyanka, Protasov Yar, Batyeva Ghora, Shulyavka were added to it. The urban areas of Svyatoshin and Demiyivka also grew out of Kyiv suburbs.

The left-bank settlements of Mykilska Slobidka and Darnitsa, territorially included in the neighboring Chernihiv province, were administratively subordinated to the district authority of the Kyiv region. Urban transport was developing. [3]

The First World War, the Revolution of 1917 and the subsequent Civil War dramatical- ly changed the gradual development of the city. City Powers in the city were constantly changing.

The number of the urban population decreased significantly: some were killed, some left the city. In 1920, there were only 376,000 inhabitants in Kyiv. At the same time, Kyiv lost its status as the capital. The capital of Soviet Ukraine was Kharkiv (from 1917 to 1934).

But already by 1923 the city area expanded almost twice due to the inclusion of 20 nearby settlements within the Kyiv borders: Darnytsia, Mykilska Slobidka, Bilichi, Sovki and other towns. [3]

In 1925 a new topogeodetic survey of the territory of Kyiv in M 1: 2000 was carried out and in 1926 the development of a new city plan began. In 1927, the Bureau of the Kyiv City Administration approved the "Provisional Rules" that governed the urban development of Kyiv.

In 1934, after the decision at the plenum of the Central Committee of the Communist Party (b) of Ukraine to make Kyiv the capital of the Ukrainian SSR again [4], arises the question of the new master plan of the city development, which would respond to the tasks of the then political and economic development direction. The spatial organization of the territory of the capital had to meet the tasks of architectural and urban planning realization of the advantages of the socialist system based on the industrial development of the socioeconomic complex of the city.

The first Soviet Master Plan of Kyiv was carried out under the leadership of P. Haustov and approved in 1938. It was also called the Master Plan for Reconstruction, which was to become "the plan of transforming Kyiv into an exemplary socialist city, worthy of the capital of the Ukrainian SSR" [5].

On the one hand, Kyiv's development along the west-east latitudinal direction (along the famous historic Via Regia) with the city's exit on the left bank of the Dnieper was to be a major novelty of the city's spatial planning. More than 20 suburban settlements were planned to be added, with an increase in the total population of Kyiv to 1.5 million people. 


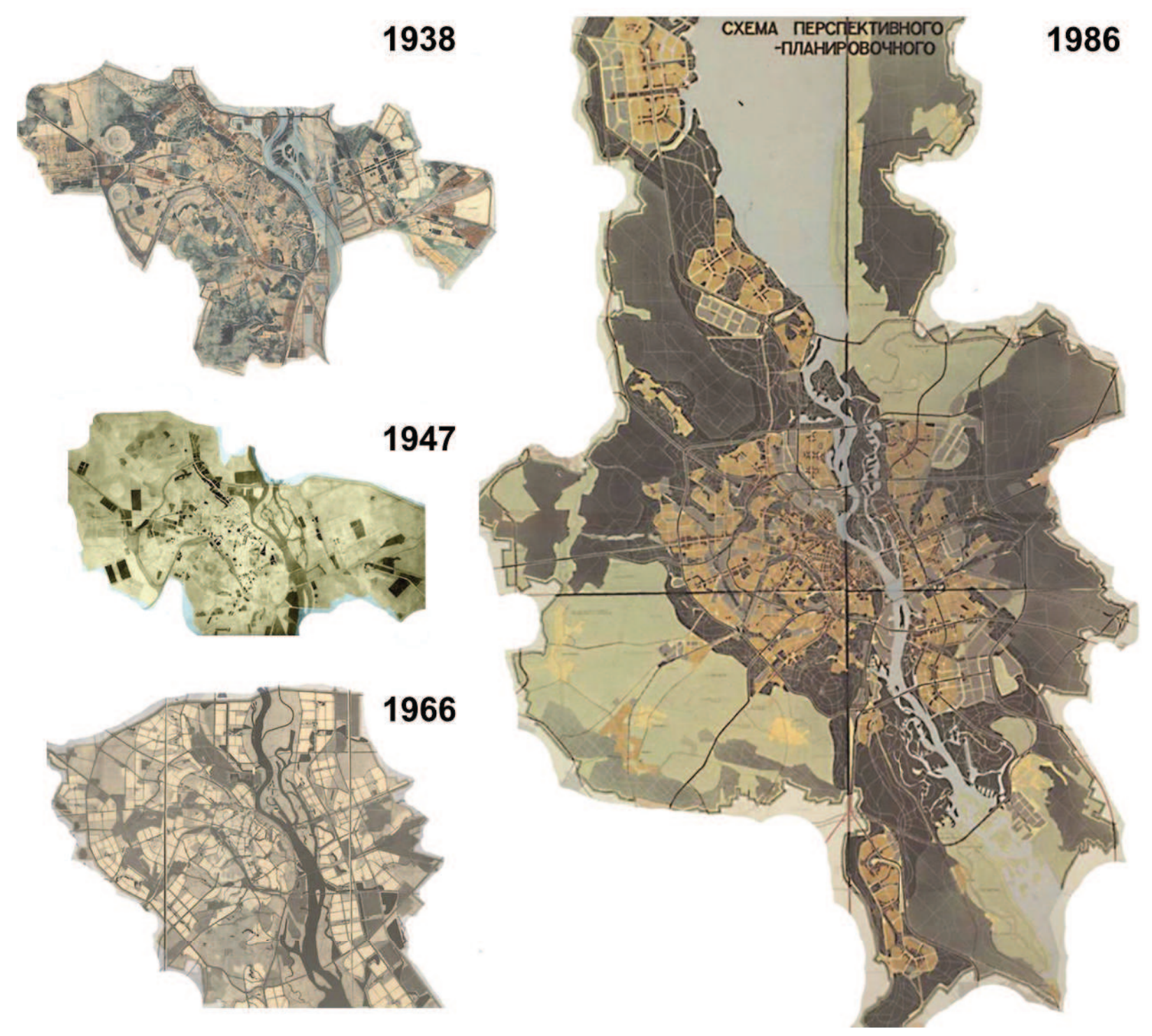

Fig. 1. The city of Kyiv Master Plans of the Soviet period (Master Plan 1938, 1947, 1966, and 1986)

On the other hand, cardinal transformations should have led to a significant increase in the spatial compactness of the city with the creation of powerful industrial and residential areas, the formation of a large-scale governmental center. [6] Unfortunately, as a result of the socalled "socialist reconstruction", over 100 of the best buildings of the 12-20 centuries were destroyed, though the beginning of the Great Patriotic War of 1941-1945 did not allow completion this ambitious plan.
At the time of Kyiv's liberation on November 6,1943 , there were only about 180,000 people in the city. The overwhelming number of industrial sites, public buildings, the city center were destroyed. The city needed a complete rebuilding. The master plan of Kyiv in 1947, executed under the direction of O. Vlasov and B. Prymak, became the reconstruction plan. The estimated population of the city in 1970 was 1.2 million people. 


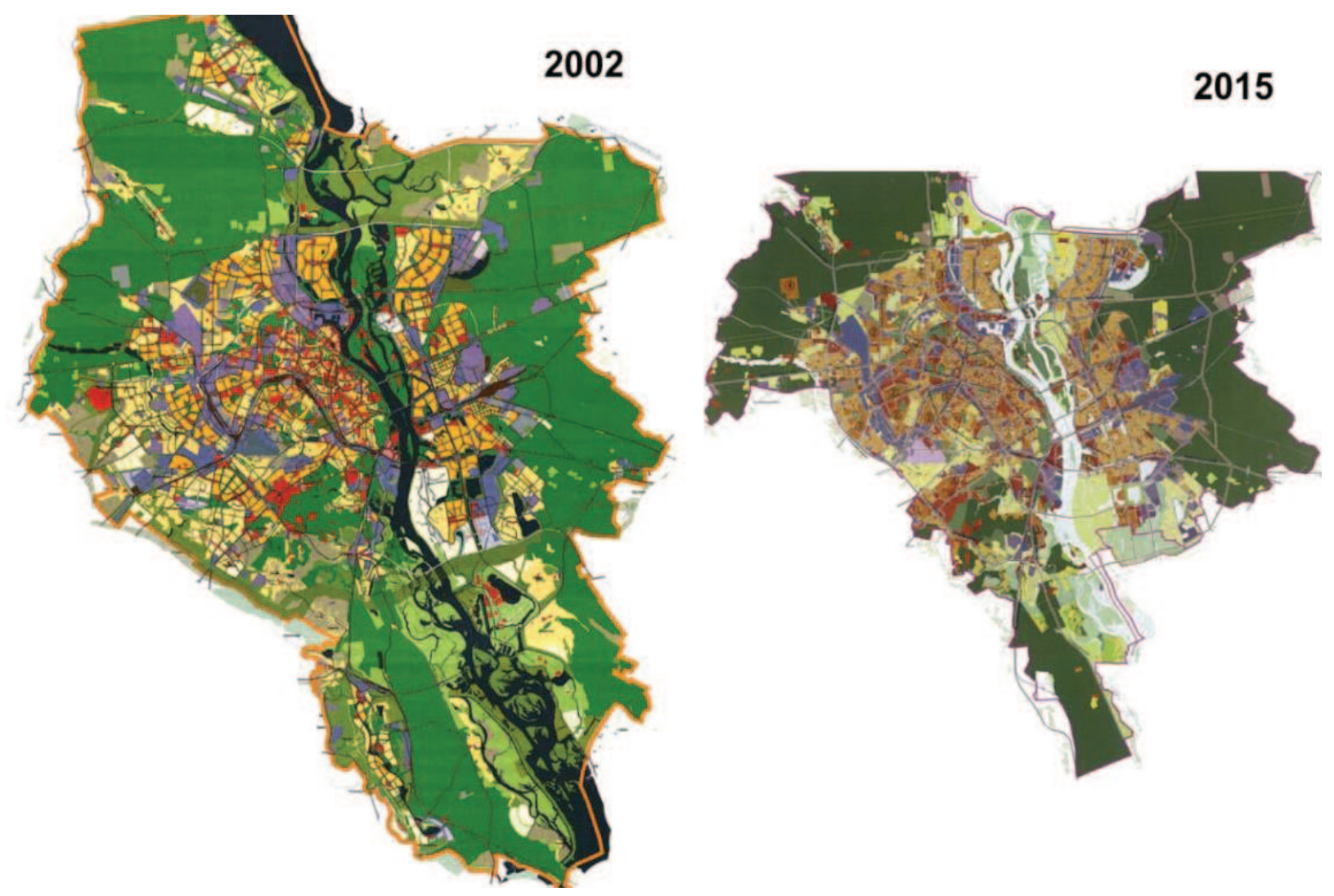

Fig. 2. Master plans of Kyiv of the contemporary period (Master Plan 2002, Draft Master Plan 2015)

The Master Plan 1947 had to solve the painful question of the reconstruction of the destroyed city. The ideas of spatial development actually formed the modern planning structure of Kyiv - the radial-ring trace of the main transport highways. There was envisaged and implemented construction of the first section of the subway from Vokzalna station to Arsenalna station (1960); Darnytskyi Railway Bridge and Paton Bridge, Khreschatyk reconstruction and extension; the formation of the Boulevards of Lesya Ukrainka and the Friendship of Nations.

Massive housing construction begins with houses of the first industrial series. There is also a girdle of areas of individual private housing that have been allowed to solve the housing problem of the growing population of the capital.

The city's development was at such a rapid pace that the estimated population of 1.2 million in 1970 was already reached in 1961.

The rapid growth rate necessitated the development and approval in 1966 of a new Master Plan of Kyiv with an estimated population of 1.8 million in 1980. This master plan became the basis for the spatial organization of modern Kyiv with a compact planning structure. New areas and residential blocks of Obolon, Troyeshchyna, Kharkivskyi, Lisovyi, Vynogradar and others are emerging. The Ring Road project and many other projects that have not yet been implemented are envisaged.

For the first time, the master plan addresses the problems of Kyiv's development in connection with the suburban area.

The last Kyiv master plan of the Soviet period was the Master Plan of 1986 (the head of the team - M. Demin, architects 
P. Kuchmarenko, E. Lishansky and others). Its main idea was to form a linear structure of a simple urban plan along the Dnieper River, creating a so-called "water green" diameter.

It was envisaged around the city of Kyiv the formation of a suburban area with the purpose of accommodation there industrial enterprises connected with the national economic city complex, development of suburban agriculture, organization of suburban mass recreation of the population. [8].

In fact, some of the city functions were outsourced outside the city of Kyiv in the adjacent administrative districts of both Kyiv and Chernihiv regions, with a total area of 1.76 million hectares [9].

The total projected population for 2005 was 3.05 million people.

Development of a linear planning structure of the city along the Dnieper River with the maximum approach of residential formations to recreational coastal territories, an increase of almost twice the length of the city in the north-south direction (from Lutezh to Khodosovka) required powerful engineering and transport communications. In particular, the extension of the subway to Dimer in the north was envisaged.

Unfortunately, the most powerful technogenic disaster of 1986 (the Chernobyl disaster), and then the collapse of the USSR with the subsequent economic crisis completely made impossible the implementation of the last Soviet Master Plan of Kyiv.

The current stage of the development of independent Ukraine is marked by only one, currently in force, the General Plan of Kyiv 2002 (Head - V. Chekmaryov).

Kyiv's acquisition of a new administrative and political status - the capital of an independent state, required the creation of an appropriate urban space. However, unfortunately, the first master plan of the capital of the period of independent Ukraine remained ideologically "Soviet". It retained the idea of spatial development of the previous master plan a significant (66\%) increase of the city area to 143403 hectares for the period up to 2020 at the expense of the adjacent territorial boundaries. [10]
At the same time, the predicted population was expected to increase only to 2.65 million people, compared to the current one -2.61 million.

It also incorrectly determined the estimated level of auto-mobilization of the population, which led to the foundation of the underdeveloped street and road network of the city in the future.

The general plan did not take into account the processes of new socio-economic processes - land splitting, ownership of land, the need to coordinate design decisions with the local authorities of the territorial entities of the Kyiv region, adjacent to the borders of Kyiv.

All this has led to an understanding of the need to develop a new master plan, taking into account the current socio-economic conditions of the city. Already in 2010, by the decision of the Kyiv City Council $[11,12]$, the Concept of Strategic Development of the City of Kyiv (the first stage of development of the Master Plan for the Development of the City of Kyiv and its Suburban Area by 2025) was approved.

The next step was the drafting of a new Master Plan for the development of Kyiv and its suburban area by 2025. According to the project, the predicted population of Kyiv is expected to grow to 3.14 million people, and the area remains at 83.6 thousand hectares.

The spatial organization is subordinated to the idea of forming a compact city with maximum use of existing territorial resources within the existing limits. The Master Plan is currently being approved and approved.

Summarizing the historical and geographical aspects of the evolution of Kyiv's spatial organization over the past 120 years, it can be stated that none of the six master plans of this period has been fulfilled. The reasons in different years were political (wars, revolutions, changes in the political structure of the country, the administrative status of the city), socio-economic (change in the level of income and social benchmarks, economic crises, change of ownership of land) and technogenic (Chornobyl disaster) cataclysms.

The spatial organization evolved from linear west-east, through compact and radial to linear north-south, and again to compact. 
For the period after the end of active hostilities in the early twentieth century, the average duration of the master plans is 18 years.

\section{B) Socio-demographic aspects.}

In urban planning the population becomes the basic characteristic of any planning formation at all territorial levels - from a separate object (number of residents), block, neighborhood, district (residential, rural, industrial number of employees, recreational - number of resting people) to the settlement, administrative district, region and country $[13,14]$. Having determined the estimated population using the standards the needs defined for all types of resources, primarily territorial ones, for the functioning and development of urban development objects.

One of the key factors that influence the accuracy of city development forecasting is the determination of population estimates. In spite of the presence of numerous methods, demographic forecasting $[15,16]$, determining the perspective population is a very difficult task. The number of factors affecting this value is very numerous, diverse and labile [17], which makes it difficult to obtain accurate forecasts.
This is confirmed by the analysis of the existing master plans of Kyiv of the 20-21 centuries. Let' consider the actual and predicted dynamics, in accordance with the general plans, population size (see Fig. 3).

According to the census of 1897 , the number of Kyiv residents was 247.7 thousand people. According to the most recent 2001 census, there were 2,611.3 thousand people, and according to the official statistics of the Main Department of Statistics in Kyiv as of June 1, 2019 , the number of permanent population reached 2,911.9 thousand people, that is, it increased approximately 12 times, adding on average a quarter of one million inhabitants every ten years.

In fact, growth rates have not been the same throughout the period. They reached their maximum values from 1945 to 1980 . Also, the transfer of administrative functions to the capital of the Ukrainian SSR in 1934 and the implementation of the plan of industrial development of the country contributed to population growth.

The maximum population decline is related to the period of occupation of Kyiv during the Second World War - 1941-1943 (from 846.7

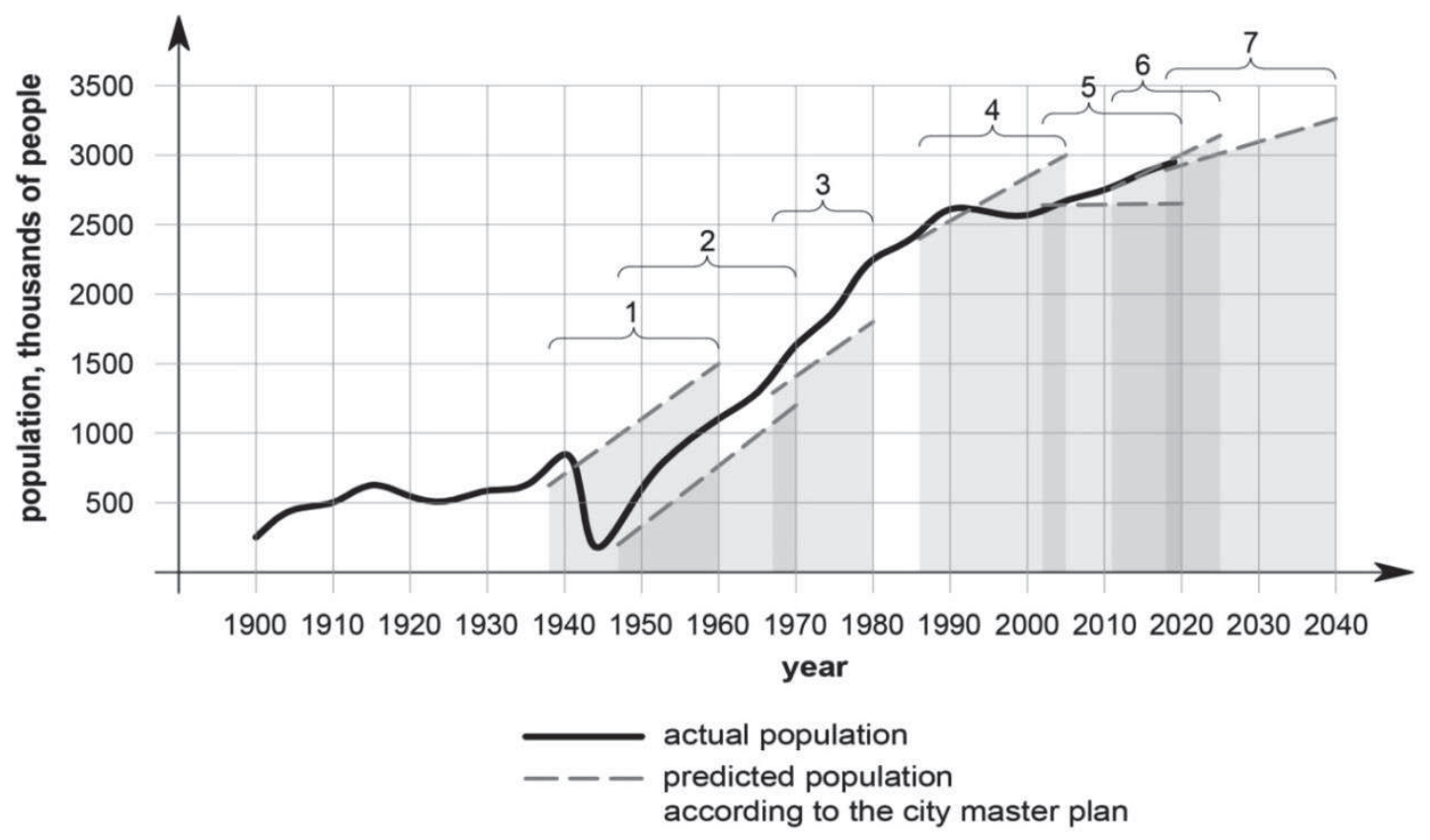

Fig. 3. Dynamics of actual and predicted population of Kyiv.

(1. Master Plan 1938, 2. Master Plan 1947, 3. Master Plan 1966, 4. Master Plan 1986, 5. Plan 2002, 6. Strategic Development Concept 2010, 7 draft Master Plan 2015) 
thousand to approximately 180.0 thousand people) [18]. The decline also occurred during the First World War and Civil War.

The last decade of the twentieth century was marked by the stabilization of the population at about 2.6 million, and only at the beginning of the twenty-first century Kyiv's population is gradually increasing.

This is connected, first of all, with the attraction of the population to the largest city in search of work in connection with the negative economic situation in the country and migration of the population from the eastern regions (Donetsk and Lugansk) and the Autonomous Republic of Crimea caused by the "hybrid" war

If we analyze the accuracy of the prognostication for the future population according to the master plans (see Fig. 3) and its actual change, we can draw the following conclusions.

No calculations of the predicted population were justified. According to the master plans of 1938 and 1986, the estimated population was 350,000 people higher from the actual. And, according to the master plans of 1947 and 1966, around 400-430 thousand less than predicted. The master plan of 2002 had an error of about 200 thousand people.

Unfortunately, since the census has not been conducted for eighteen years, we do not know the exact figure. Thus, the predicted value of the population under the project of the new master plan is more likely to be incorrect.

\section{C) Legislative and regulatory aspects.}

The questions concerning methodology for predicting the spatial development of urban systems are constantly being the subject of research on urban planners $[19,20,21,22$, etc.].

The huge theoretical and practical achievements found its concentrated expression in the legislative and regulatory framework for the development of draft master plans for settlements.

The key legislative and regulatory documents that regulate these issues include:

1) On Regulation of Urban Planning Activity (Law of Ukraine No. 3038-VI of
February 17, 2011);

2) DBN B.1.1-15:2012. Composition and content of the master plan of the settlement;

3) DBN B.2.2-12:2019. Planning and development of territories;

4) DSP 173-96. State sanitary rules for planning and construction of settlements;

5) DBN B.2.2-3:2012. Composition and content of the historical and architectural reference plan of the settlement.

The first Soviet regulatory document governing the planning of settlements was "Temporary rules and regulations for the design and construction of buildings and structures" (PIN 1929). These "Rules ..." were abolished and replaced by "Rules and norms for urban development, design and construction of buildings and structures" (PIN 1930). In 1958, they were replaced by the "Rules and norms of planning and urban development" (SN 41-58). The following regulatory documents on steel design - SNIP II-K.2-62, SNIP II-60-75, SNIP 2.07.01-89, DBN 360-92. And since October 1, 2019, the new DBN B.2.2-12:2019 "Planning and development of territories" comes into force.

In the last decades of the Soviet period, the main document was the instruction of BSN 3882 "Instruction on the composition, procedure for development, coordination, approval of schemes and projects of district planning, planning and development of cities, towns and rural settlements". According to this instruction, the master plan was to be developed for a design period of 20 years, with the allocation of the first stage of construction.

As mentioned above, according to the Law of Ukraine "On Regulation of Urban Planning Activity" and DBN B.1.1-15:2012, the validity period of the general plan of the settlement is not limited and during the determination of the main technical and economic indicators the stage 1 should be allocated (15-20 years).

This "temporary" unlimitedness has caused numerous problems in the process of approval of the last master plan of Kyiv (project of 2015), since there was a discussion about the 
legitimacy of developing a new master plan despite the fact that the validity of the previous master plan is "not limited" and, accordingly, it is valid.

However, as the analysis of the master plans of the Soviet and modern periods practice implementation shows, the necessity of developing a new master plan, first of all, is determined by the peculiarities of the sociopolitical and socio-economic reality of the city's existence. Even with the pre-determined need to develop a master plan every 20-25 years (VSN 38-82), the actual development period was shorter - 17-18 years, reaching 910 years during periods of tumultuous crisis.

The factors (circumstances) that caused fundamental changes in the conditions of existence of both the city of Kyiv (in particular, the dynamics of its population, see Fig. 4), and the country as a whole can be attributed to:

A. negative (those that slow down the development of the city):

- World War I, 1914-1918;

- $\quad$ the Revolution of 1917;

- the Civil War, 1918-1922;

- World War II (Great Patriotic War), 1941-1945;

- Chornobyl technogenic disaster, 1986;
- collapse of the USSR with the subsequent economic crisis, 1991;

- World Economic Crisis, 2008

B. positive (those that stimulate urban development):

- the country industrialization plan implementation with the development of industrial base of the city, beginning 1929.

- transfer of capital from Kharkiv to Kyiv, 1934;

- the program of reconstruction of the destroyed city after the Second World War, 1946;

- implementation of the program of mass housing construction ("khrushchevka"), 1957

- short-term economic growth of the period of independent Ukraine, 19982006;

- stimulation of housing construction due to internal migration of the population to the capital as a result of the military conflict in Donbas, 2014

Frequency of occurrence of negative (unpredictable) influencers on the development of the city of Kyiv for the period under consideration is approximately 17 years, which con-
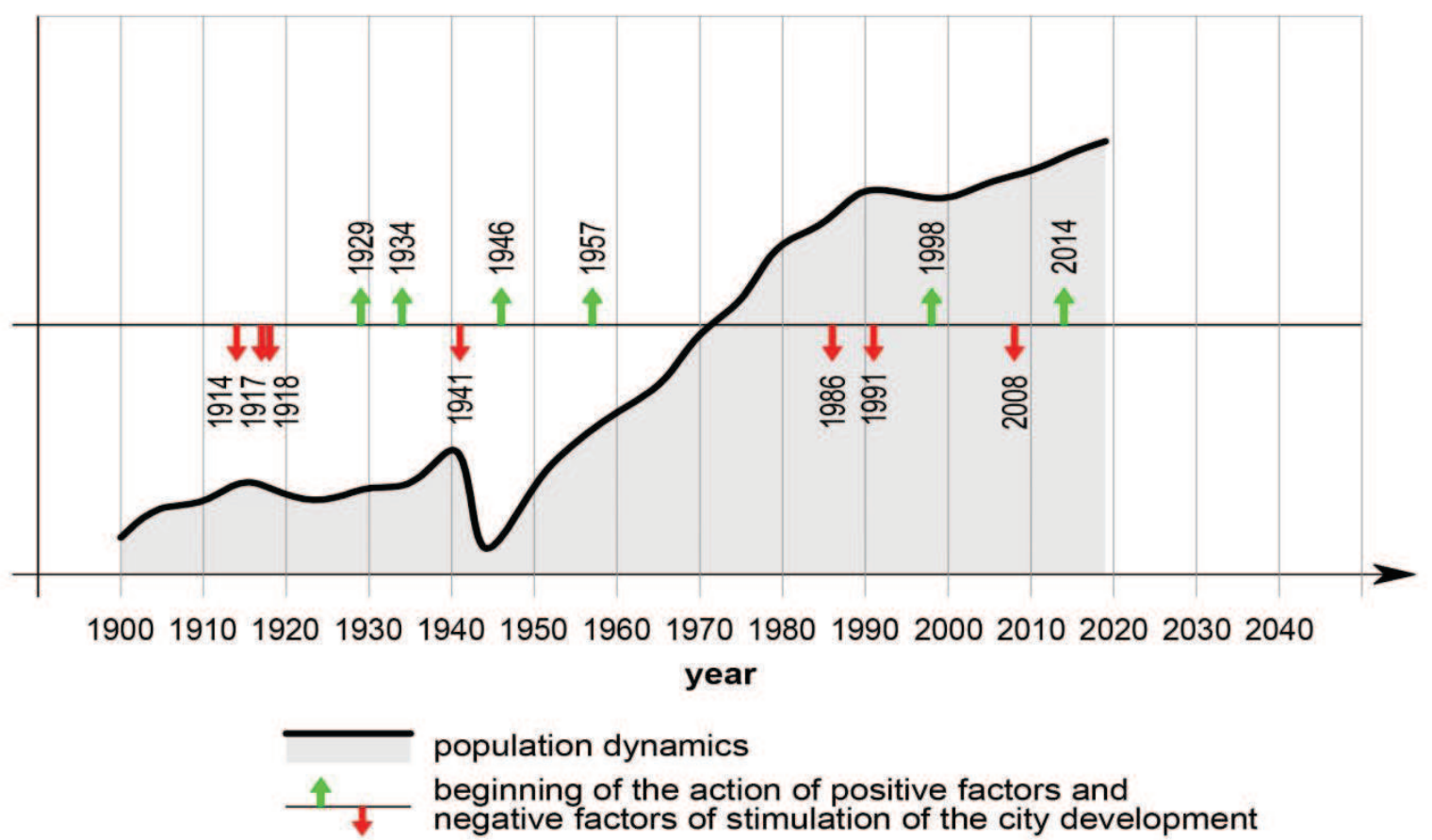

Fig. 4. Impact of positive and negative factors on the dynamics of the actual population of Kyiv 
firms the doubt of determining the validity of the city master plan as unlimited. To the same extent, this also applies to other settlements, since negative factors of influence are common to the whole country. Regarding the frequency of changes in the basic normative documents on urban planning, it is also possible to note some correlation with fundamental political and socio-economic changes in the life of the country. For example:

- the introduction of temporary (PIN 1929) and subsequently permanent (PIN 1930) came after the realization of the need to move from agricultural orientation to industrialization of the country. In 1927, the 15 th Congress of the CPSU (b) adopted the "Directives for the drafting of the first five-year plan for the development of the economy of the USSR."

- SN 41-58 are adopted after the approval of the programs of mass housing construction (the so-called modern "Khrushchevka") in 1957.

- DBN 360-92 came into force after Ukraine gained independence (1991) and drastically changed political and socio-economic orientations.

Unfortunately, the latest DBN B.2.212:2019, which should meet the current global trends and challenges of urban environment formation in the conditions of neo-economy and spread of innovative technologies, remained ideologically "Soviet".

\section{CONCLUSIONS AND RECOMMENDATIONS}

The study made it possible to formulate the following results:

A. No Master Plan of the city of Kyiv has ever been implemented. It is connected with the political, ideological, socio-economic conditions of the society's development, as well as the consequences of the biggest technogenic disaster - the Chornobyl accident.

B. The statutory requirement for an unlimited duration of the master plan requires adjustment. The most rational is the term 20-25 years. And, given the speed of change in the world's scientific, technical and socioeconomic factors influencing people's aware- ness of urban comfort environment, it should be no more than 15-20 years.

C. Transformation of the spatial organization model of the territory of the city of Kyiv took place cyclically - from dispersed in the pre-Soviet period, then linear west-east, through compact and radial-circular, to linear north-south, and again to compact.

D. The population dynamics of the city are directly linked to both positive and negative influences and are extremely difficult to predict. Not even once during the study period (120 years) was an accurate demographic prognosis possible. The fallacy ranged from 200,000 to 450,000 people in both directions.

Summarizing the above mentioned, it can be said that, before approving the draft new Master Plan for the City of Kyiv (commencement of 2015), a census should be conducted and the actual indicators of the sociodemographic structure of the city's population should be determined.

Now the main thing. In our opinion, taking into account the current socio-economic factors, the actual state of deterioration of fixed assets, objects and networks of engineering and transport infrastructure of the city, the fundamental idea of the new Master Plan should not be the development of new territories, but a cardinal complex reconstruction of the city of Kyiv.

\section{REFERENCES}

1. On Regulation of Urban Planning Activity, 2011. Law of Ukraine. Access mode: https://zakon.rada.gov.ua/laws/show/3038-17.

2. Stebletska Yu., 2014. Development planning of Kyiv: historical and geographical aspects. Geography Kyiv. No. 1 (62). 70-73.

3. Pankova E.V., 2003. Tourist studies. Alterpress, Kyiv. 352

4. Yefimenko G., 2001. This Day in History. Transfer of the capital of the Ukrainian SSR to Kyiv. Access mode: https://www.jnsm.com.ua/h/0624Q/

5. From Ukraine to the USSR: All-Ukrainian Science Conf. materials, on behalf of the 80th anniversary of the transfer of the capital of So- 
viet Ukraine to the city of Kyiv, 2014. Access mode:

http://www.nas.gov.ua/UA/Org/publication/boo ks/Pages/default.aspx?OrgID=0000271.

6. Haustov P.P., 1938. Construction in 1938 and planning of Kyiv. Architecture of Soviet Ukraine. No. 4/5, 6-10.

7. Kilesso S.K., 1987. Kyiv architectural. Photo album. Builder, 19.

8. Paleha Y.M., 2017. Geographical features of planning of Kyiv development at the present stage. Ukrainian Geographical Journal. No.4, 39-48.

9. On the master plan for the development of Kyiv, 1986. Resolution of the Central Committee of the Communist Party of Ukraine and the Council of Ministers of the Ukrainian SSR of May 13, No.177. Access mode:

https://zakon.rada.gov.ua/laws/show/177-86$\% \mathrm{D} 0 \% \mathrm{BF}$

10. Kyiv Master Plan for the period up to 2020. Main provisions, 2001. Kyivproject JSC, Kyivgenplan Institute. Access mode: https://drive.google.com/file/d/0BxbGBoNdblj 6MDBuSkdHS1F5V1E/view.

11. Concepts of strategic development of the city of Kyiv (the first stage of development of the Master plan of development of the city of Kyiv and its suburban area to 2025), 2010. Decision of the Kyiv City Council of September 16, 2010 No.35/4847.

http://kiev4you.org/gif/genplan2025.pdf

12. The Master Plan of Kyiv. Main provisions, 2011. CO., Institute of the Master Plan of Kyiv, Access mode:

https://ips.ligazakon.net/document/view/NT020 5 ? an $=543$.

13. DBN B.2.2-12:2019, 2019. Planning and development of territories. Kyiv, Ministry of Regional Development of Ukraine, 177.

14. Zablotsky G.A., 1975. Social bases of urban development (social problems of settlement). Moscow. Building construction, 88.

15. Team of authors, 2006. Comprehensive demographic forecast of Ukraine for the period up to 2050. Libanova E.M., Kyiv. Ukrainian Center for Social Reform. 138.

https://www.idss.org.ua/monografii/Prognoz $\% 2$ 0Ukrain.pdf.

16. Ustinova I.I., 2015. Theoretical principles of wave urbanistics. Underwater Technologies, Iss.01, 33-42.

17. Pleshkanovska A.M, 2009. Demographic preconditions for urban reconstruction. Urban planning and territorial planning. KNUBA, No.33, 345-355.

18. Pleshkanovska A.M., Savchenko O.D., 2019. Epochs and cities. Logos, 264.

19. Bilokon Yu.M., 2002. Management of Territorial Development (Planning Aspects) Kyiv: Ukrarkhbudinform, 148.

20. Demin N.M., 1991. Management of urban development systems development. Builder, 184.

21. Ositnyanko A.P., 2005. Planning of city development: Monograph. Kyiv, KNUBA, 385.

22. Filvarov H., Pleshkanovska A., 2010. Major Methodological Trends in the Development of the New Master Plan of Kyiv City. Spatial Development of the Polish and Ukrainian Big Cities at the Beginning of the 21st Century, Lodz., 55-62.

23.Strategy vs. Flexibility: How Often General Plan Updates Should Be Done, 2018. Investgazeta.ua. October 24, Access Mode https://investgazeta.ua/blogs/strategiya-vsgnuchkist-yak-chasto-treba-onovlyuvatigenplani-mist.

24. Herzberg L.Y., 2018. Updating the methodological bases of master plans development in the context of modern threats and challenges to urban development. CNIIP of the Ministry of Construction of Russia, Moscow, 91-97.

25. Gleba V., 2011. Improvement of the system of planning the development of the territory of settlements. Public administration and local selfgovernment, No.4 (11), 95-105.

26. Dyuzhev S.A., 2011. The concept of strategic development of the city of Kyiv: problems of urban planning, theory, methodology, regulatory framework. Urban planning and territorial planning, KNUBA. No.39, 136-155.

27. Vadimov V.M., 2000. City and River (planning aspects). Monograph. Kyiv, Poltava, Archeology, 214.

28. PleshkanovskaA.M., 2011. Reconstructive activity as a condition for sustainable development of a large city. Experience and prospects of urban development in Ukraine. DIPROMac. No.20, 44-54.

29. Meshcheryakov V.V., 2012. Urban planning as a component of managing the territorial development of a city. Public Administration: Improvement and Development. Iss.09. Access mode:

http://www.dy.nayka.com.ua/?op=1\&z=469. 


\section{Генеральный план города: проблемы методологии прогнозирования (на примере генеральных планов г. Киева)}

\section{Алла Плешкановская}

Аннотация. В статье освещены результаты анализа теории и практики прогнозирования перспектив пространственного развития крупного города (на примере генеральных планов города Киева).

На базе ретроспективного анализа охарактеризованы периоды разработки генеральных планов Киева - допланировочный, период вхождения в состав Российской империи, советский и современный [1].

Исследование выполнено в разрезе трех ключевых групп факторов, входящих в состав методологической базы разработки градостроительной документации местного уровня - генеральных планов населенных пунктов. А именно - историко-географические, социальнодемографические и законодательно-нормативные аспекты влияния на прогнозирование пространственного развития города.

Подробно рассмотрены генеральные планы Киева периода XX-XXI века и установлены этапы трансформации пространственной орга- низации территории Киева. Концептуальные идеи эволюционировали от линейной в направлении запад-восток к линейной в направлении север-юг, от рассредоточенной до компактной.

Проанализировано соответствие динамики фактической и прогнозируемой численности населения Киева с учетом политические и социально-экономические особенности того или иного периода развития общества.

Сделан вывод о чрезвычайной сложности прогнозирования перспектив развития крупнейшего города. Рассмотрены причины (неточность демографических прогнозов, контринтуитивность развития сложной градостроительной системы, несовершенство законодательно-нормативной базы) невозможности полной реализации генеральных планов населенных пунктов, в частности, города Киева.

Приведены рекомендации по совершенствованию нормативно-правовой базы разработки генеральных планов населенных пунктов. Сформулировано авторское видение перспективных направлений пространственной организации территории города Киева, в составе проекта генерального плана, который сейчас разрабатывается.

Ключевые слова. Генеральный план, пространственное развитие, численность населения, демографический прогноз. 